\title{
The doing of the little righteousness - the on-going search for justice after the TRC
}

\begin{abstract}
Taking as point of departure, South African theologian Dirkie Smit's theological oeuvre, particularly his theological reflections issues such as politics, justice, peace and reconciliation, the essay moves on to focus on Mahmood Mamdani's view of the differences between the Nuremberg trials, South Africa's political negotiations held in Kempton Park and the TRC and his critique of the latter. This once again raises the matter of justice, different forms of justice - especially as either "victor justice" or "survivor justice" and the consequences of this for the TRC and for Christians in the call for the doing of justice. With reference to the views of Desmond Tutu (especially his understanding of the concept of ubuntu), it is suggested that the TRC's only choice was not just between retributive and restorative justice, revenge and forgiveness, but that it was incumbent upon it to advance the gains made at Kempton Park and to move from victim's justice to survivor's justice and from the foundation of political justice to social justice which it did not do.
\end{abstract}

\section{POlitics, PEACE, JUSTICE, RECONCILIATION}

Dirkie Smit's impressive theological oeuvre defies simple characterisation. He is at once the consummate Reformed theologian yet thoroughly ecumenical; he revels in complex theological and philosophical argumentation but is simultaneously the epitome of clarity. Systematics is his field, yet he burns with ethical concern; himself eminently peaceable, yet in his own way he engages every battle for justice, peace and reconciliation. He is the last to call himself a politician, not even an "accidental" one, ${ }^{2}$ but his work shows that he, like Karl Barth, knows that

Christianity has do to with politics thus theology is itself political action. There is no theological reflection or elucidation, no sermon and even no catechism for children which does not imply political meaning the Kingdom of Jesus Christ is itself a political reality (Barth 1962:17177; cf. Smit 2007:361).

Smit's work reflects passionate defence of those social, ethical, and political issues that are of great import to South African society in general and to the Christian community in particular, yet he is comfortably global in his thinking. ${ }^{3} \mathrm{He}$ is convinced that for Reformed Christians

1. Allan Boesak is Theologian in Residence at the Institute for Race, Reconciliation and Social Justice, University of the Free State and Extraordinary Professor at the Faculty of Theology, Stellenbosch University.

2. See Allan Boesak, Running with Horses. Reflections of an Accidental Politician (2009).

3. Cf. The collections of excellent essays where Smit addresses a wide range of issues, some pure theoretical theological reflection, others practical, directly addressed to pastors and other audiences, but always rich, clear and elucidating. Cf. As just a few examples of this wide ranging, insightful and always relevant thinking: Reformed Faith, Justice and the Struggle against Apartheid; On the Impact of the Church in 
NGTT: Oopbron - http://ngtt.journals.ac.za

"involvement in political and economic life is clearly a matter of faith" (Smit 2007:383) just as he knows that "more fundamental than any possible political, social or ethical use of the Bible, is the fact that reading the Bible itself is political" (Smit 2009:53, 54).

What is always striking is not just that the inherent humility Smit exhibits does not quite succeed in subsuming the brilliance of his work, but that in the broad range of his theological endeavours the themes he constantly returns to do characterise his theological commitments: politics, peace, reconciliation, justice. As theologian he captivates me because I sense in him the theologian as described by James Cone:

The theologian is before all else an exegete, simultaneously of scripture and of existence to be an exegete of existence means that scripture is not an abstract word, not merely a rational idea. It is God's Word to those who are oppressed and humiliated in this world. The task of the theologian is to probe the depths of scripture exegetically for the purpose of relating that message to human existence (Cone 1997:33).

Herein Smit presents himself in the words of Karl Barth - and one must read him like one reads Barth. It is, Smit says, "not very heroic - very unassuming”, an effort towards human righteousness that is "imperfect, fragile and highly problematical" (Smit 2007:367). Nonetheless, it is the call of the kingdom of God, and even though it sometimes demands "swimming against the stream", it is prayerfully ("Your kingdom come!"), "accepting the responsibility for the doing of the little righteousness" (Smit 2007:359-378). Secure in the knowledge that Jesus came, "and since He came, we are sanctified for the service of this King", we work for the coming of this kingdom (Smit 2007:361). This service takes the form of a "revolt", "a struggle", not against people, but against a"plight" that has stricken all humanity, "a disorder which both inwardly and outwardly controls and penetrates and poisons and disrupts all human relations and interconnections" (Smit 2007:362). While waiting for the kingdom we hasten towards it, determined

to do resolutely what we can here and now on this side in orientation and with a view to God's side, without claim or illusion, not trying to anticipate what only God could begin and finish, but rising up for righteousness and order in the midst of disorder and opposition (Smit 2007:363).

Even though this is done "in weakness", we engage it because "something [then] happens" (Smit 2007:365).

Twice Smit returns to Barth's injunction that no matter how unassumingly, we must still engage in this battle, to "say Yes and No and often to do it resolutely" - albeit not absolutely - "not afraid of taking sides for or against" - in freedom, that is - with a certain distance, a certain hesitancy, for we must remember that our total yes, a "definitive decision" is "always for human beings and never for any cause" (Smit 2007:369).

At the end of this fascinating piece on Barth, Smit - always somewhat reticent - finally takes ownership in an expression of the need for support of

South Africa after the Collapse of the Apartheid Regime; The Symbol of Reconciliation and Ideological Conflict in South Africa; Theological Assessment and Ecclesiological Implications of Human Freedom.

4 This sentence, taken from Karl Barth's 1962 Theology Today article, is the title of Smit's essay The Doing of The Little Righteousness On Justice Barth's View of the Christian Life (Smit 2007:359-378). In my view, this is one of the finest theological pieces in Smit's highly remarkable oeuvre. 
NGTT Deel 54, Nommers $3 \& 4$, September en Desember 2013

many South African Christians in their participation in their on-going struggle, albeit small, relative, provisional and ambiguous to contribute to a little human righteousness, while praying sol iustitiae illustra nos, and waiting (Smit 2007:378).

I find this theological reflection quite characteristic of Dirk Smit's work and his person, and in offering my own reflections here, I wish to pay tribute to that invaluable contribution to Christian faith as politics, theological engagement as a struggle for peace, reconciliation and justice. As he says of Barth, "beneath the seemingly quiet and peaceful surface" Smit's work resonates with these themes and never more so as when he struggles with South Africa's truth and reconciliation efforts, Reformed faith and confessions, and our endeavours towards justice.

As is clear from Smit's reflections, Barth's terminological intention is Gerechtigkeit (justice), constantly translated as "righteousness" in this piece, but his reference is to the terms in the Hebrew Bible, mishpat and tsedega, and the New Testament word for justice, dikaiosune, also usually translated in most English translations of the Bible as "righteousness". ${ }^{5}$ This biblical justice is the undoing of injustice and the bringing about of justice for those who are vulnerable and wronged, the poor and the lowly. It is Yahweh's "abiding cause" (Wolterstorff 2008:81) as well as that of Jesus, "the One who brings justice" (Wolterstorff 2008:115ff.). This is how I believe Smit understands it and this is how "righteousness" will be understood in this contribution.

This essay will continue the conversation with the Truth and Reconciliation Commission's (TRC) monumental work and will raise questions from what I consider to be less explored perspectives.

Taking as point of departure Mahmood Mamdani's intriguing thoughts on the Nuremberg trials, South Africa's political negotiations held in Kempton Park and the TRC (Mamdani 2010), we shall once again reflect upon the issue of justice, the way it is understood and the consequences of that understanding for the TRC and for Christians in the call for the doing of justice.

\section{Nüremberg; Kempton Park and the question of Justice}

In a profound and provocativelecture Mahmood Mamdani, the world renowned social scientist of Uganda's Makerere University, reflects upon the difference between the Nüremberg trials, the Kempton Park negotiations and the TRC. He begins naming "the two great human wrongs that occurred in the twentieth century - the Holocaust and apartheid" (Mamdani 2010:1) He then contrasts the ways in which we have settled accounts "with these great crimes against humanity": with criminal trials in Nüremberg and with a political settlement in Kempton Park.

Mamdani makes the point that, while the world has become fascinated with South Africa's TRC, it has not taken the lessons from Kempton Park as seriously as it should have. To begin with, whereas Nüremberg shaped a notion of justice as criminal justice, few recognise that

\footnotetext{
5 For a discussion of the extraordinary difficulties English translators have had with these terms cf. Wolterstorff 2008:69-75. Wolterstorff argues convincingly that the biblical authors do not deal in a theory of justice, but in the truth that justice is Yahweh's cause in which Israel is called to participate by pursuing justice. "It is not the abstract entity justice as such that God loves.
} 
NGTT: Oopbron - http://ngtt.journals.ac.za

Kempton Park calls on us to think of justice primarily as political justice. Furthermore, and more importantly, whereas Nüremberg has become the basis of a notion of victim's justice - as a complement of rather than a contrast to victor's justice - few acknowledge that Kempton Park provides the basis for an alternative notion of justice, which Mamdani calls "survivor's justice" (1). South African's failure to understand this distinction contributes to the limitations of the South African transition, which Mamdani traces to "the failure to broaden the discussion of justice beyond political to social justice" (2).

Mamdani previously (1996) wrote a telling critique of the workings of the TRC. In it he argued that the problem was that the TRC made an improper distinction, namely between victims and perpetrators. Properly, the distinction should have been between beneficiaries and victims of apartheid. While some white South Africans perpetrated human rights crimes (for which the TRC tried to hold them accountable), all white people benefited from apartheid. This, Mamdani said, is how we should address the questions of guilt, repentance, reparations and restitution. He then warned:

If reconciliation is to be durable, would it not need to be aimed at society (beneficiaries and victims) and not simply at the fractured elite (perpetrators and victims)? And does not justice then become a demand for systemic reform of society as a whole, so that the "target" is all who benefited, rather than just the personal conversion of "the perpetrator"? (Mamdani 1996.).

This issue has been pursued and, following economist Sampie Terreblanche, it has been pointed out that the TRC has indeed failed to understand the systemic nature of the wrongs perpetrated against an economically oppressed and exploited population. The TRC also failed to grasp the causative role played by the systems of white political dominance, racial capitalism and apartheid over a considerable period of time in bringing about and sustaining white wealth and privilege on the one hand, and black poverty, black deprivation and black humiliation, on the other (Boesak 2005:192-193). That point was well taken.

Now, however, Mamdani both broadens and deepens his critique. In the popular imagination, he says, the South African transition is mainly identified with the work of the TRC. However,

[t]he TRC had more in common with the logic of apartheid than is often realised. First, when the TRC held individual state officials criminally responsible, it was only for actions that would have been defined as crimes under apartheid law. It did not hold them accountable for the violence that was authorised by apartheid law, but only for the violence beyond the law, violence of which they were individual authors rather than implementers. When it held them accountable, it was for excess, for violence beyond the law. By ignoring the violence authorised the apartheid state and apartheid law, the TRC ignored political violence. Instead, it set out to identify criminal violence - violence that exceeded political orders, violence that would have been punished as crime even under apartheid law had it been fully implemented. In other words, the TRC upheld rather than question the rule of law identified with apartheid (2010:5).

In my view this analysis has immense consequences. Without doubt it had an enormous impact on the outcomes and conclusions of the Commission. Not only was the work of the TRC limited to a rather random period of South Africa's history - it did not include the historical wrongs of colonialism and slavery - but, regarding the period, it did focus on the apartheid era; it worked only with what was lawful under apartheid law. Not only were historic 
NGTT Deel 54, Nommers $3 \& 4$, September en Desember 2013

injustices ignored, but whole communities - victims of historic wrongs - were thereby also excluded from consideration for justice.

But this is an entirely different matter. The TRC argued, Mamdani writes, that most rights' violations under apartheid - roughly over half of it - had occurred during the period of transition from apartheid, and not during apartheid proper; hence the strange outcome of the statistical analysis made by the TRC. Working from the Truth and Reconciliation Commission Report (Volume 1, page 172, paragraph 25), Mamdani (2010:5) calls the TRC's lists and rankings of "victim organisations" and "perpetrator organisations". The list of "victim organisations" is headed by the ANC followed by the Inkatha Freedom Party (IFP), with the South African Police in seventh place. The IFP comes first among "perpetrator organisations", the ANC second, the SAP third and the South African Defence Force is in fourth place.

Since the TRC also declared apartheid a "crime against humanity", Mamdani (2010:6) feels compelled to ask: Who authored this crime? "If", he states, "not only most victims, but most perpetrators, were black people, then was apartheid, this 'crime against humanity', primarily a "black-on-black" affair?"

I believe this is a most disturbing question, but a necessary one. Beyond political theatre and human drama, what precisely, then, was the efficacy of the TRC? What purposes toward real truth and reconciliation did it serve? That would mean that black people would now have to live with the most painful of contradictions: being both victims of apartheid and perpetrators of a crime against humanity - in effect against themselves. Where does this leave white South Africans, not just as individual perpetrators but as collective, generational beneficiaries of apartheid? This surely is an issue of justice, but one far beyond social justice alone. At another level this raises questions we cannot pursue here: What is the meaning of "violence"?; and, more importantly: What does this mean for the forgiveness black South Africans were called upon to extend?

However, Mamdani goes yet further still: The expectation would have been that, since Kempton Park moved beyond the Nüremberg paradigm (moving from criminal justice to political justice and from victim's justice to survivor's justice), the TRC would, as it were, complete the circle by moving from political justice to social justice.

Kempton Park did not ignore the question of justice, Mamdani insists. On the contrary, it provided us "with a radically new way of thinking about justice" and this represents "a double breakthrough" (2010:6). First, it distinguished between criminal, political and social justice - so as to prioritise political justice: the reform of the political system above the other two. This is important, since the object of criminal justice is punishment; that of political justice is political reform. Second, "it decriminalised the other side so as to treat it as a political adversary". Finally, and this is a hugely important point to which we shall return, political justice prioritises the claims of the living over those of the dead (2010:8).

\section{A PARADIGM SHIFT}

We are following Mamdani yet another step forward. Whereas Nüremberg was "backward looking" in its preoccupation with justice as punishment, Kempton Park sought a balance between past and future, between "redress for the past and reconciliation for the future" (2010:7). The "real trade off" between truth and amnesty did not occur at the TRC, but at 
NGTT: Oopbron - http://ngtt.journals.ac.za

Kempton Park: "The amnesty offered perpetrators and the stay offered beneficiaries was in return for political reform. It is at Kempton Park where the rules changed" (2010:7). Mamdani is right. The rules agreed on were the same for all survivors, beneficiaries and victims alike, not just for surviving victims. "The shift in paradigm changes the meaning of survivor to include all those who survived yesterday's catastrophe, apartheid" (2010:7).

We have mostly missed the extraordinary magnanimity in and theological import of this: that we speak of both the victims and the beneficiaries, even the beneficiary as perpetrator, as survivors. In a real sense victims of apartheid survived not simply because they were left alive, but because they resisted and overcame the systems of oppression despite the determination of the beneficiaries to uphold these. "Looking forward", Kempton Park not merely shaped a common future because we had no other choice: there was no clear victor in the struggle against apartheid. One can say that perhaps only in the military sense. In all other ways apartheid was defeated, rendered unsustainable (Boesak, 2009:157195; 338362).

Therefore, the process of forgiveness which the TRC worked with in terms of selected individuals had already begun, but only begun, since its meaning and completion lies in the fulfilment of social justice. The reconciliation we ascribe to the TRC began here, on behalf of the nation, with the inclusion of yesterday's victims, yesterday's perpetrators and yesterday's beneficiaries. This is what the shift from victim's justice to survivor's justice means (Mamdani 2010:7). The creation of a common future is hereby not just the result of cold, calculated real politik (there was no clear victor), but of a willingness to take the risk of inclusive solidarity in order to make possible the reconciliation the TRC could have vested with further meaning.

Exchanging amnesty for political reform - or theologically speaking, revenge for forgiveness - is reflected also in the central place the writing of the new Constitution claimed in those negotiations at Kempton Park. Mamdani criticises the South African Constitution because of its private property clause which, he argues, obfuscates the truth regarding the violations of property rights black people suffered under apartheid and enabled the TRC to ignore violations of property rights when "most group violence under apartheid constituted extra economic coercion, in other words, it was against both person and property" (2010:8). ${ }^{6}$ Again Mamdani has a point.

Recognising that, my argument is different. The Constitution as a whole, in its humanising intent, needs to be seen not so much as a conclusion to negotiations, but as the framework for genuine, continuing political reform. It is intended as the foundation of an on-going process at the heart of South Africa's transformation project, a commitment to the furthering of justice to which all South Africa's people, as survivors of the apartheid tragedy, are held. The legislation that created the TRC constituted the legal framework, which itself fell within the mandate for on-going, systemic justice given by the Constitution. What Kempton Park achieved was what the TRC should have taken forward: the prioritisation of political justice over criminal justice meant to give preference to the demands of the living over those of the dead in a demand for social justice.

6 "When the TRC made public its tally of victims of human rights violations as a little over 20,000, it was telling the public that it did not consider victims of pass laws, that is, all blacks in South Africa, or of forced removals, their numbers running in the millions, as victims of human rights violations" Mamdani (2010:8). 


\section{GIVING PREFERENCE TO THE LIVING}

For those parts of Africa torn apart by internal political conflict - from Ivory Coast to Liberia, to Sudan and Kenya and from Zimbabwe to Congo - the great lesson is to remember what happened at Kempton Park. Precisely because its recommendations were not mandatory, the TRC had the opportunity to explore the future beyond Kempton Park, the step after political justice. The TRC could not make law, but it could push forward social justice as a social project to lay the basis for social reconciliation, to expand the notion of justice so as to make reconciliation durable (Mamdani 2010:9). The TRC failed in what is "the greatest challenge South Africa faces today" (Mamdani 2010:10). In other words, unlike Nüremberg, the TRC had the opportunity to give preference to the demands of the living over those of the dead by insisting on social justice. Instead of moving forward with regard to social justice, the TRC moved backward toward Nüremberg. Defenders of the TRC would argue that what South Africa chose in the TRC was exactly the opposite of Nüremberg. This is done, in any case, by Archbishop Desmond Tutu, Chair of the TRC and arguably one of the best to explain the work of the TRC. The Nüremberg option was not really a viable option at all, Tutu writes in his insightful and hugely influential book, No Future without Forgiveness (1999:24). Nüremberg imposed victor's justice, a term Mamdani also uses. In South Africa, neither side could impose victor's justice because neither side won the decisive victory that would have enabled it to do so. Like others, Tutu sees as decisive the fact that

the security forces of the apartheid regime would not have supported the negotiated settlement which made possible the "miracle" of our relatively peaceful transition from oppression to democracy had they known that at the end of the negotiations they would have faced the full wrath of the law as alleged perpetrators. They still controlled the guns and had the capacity to sabotage the whole process. If we had insisted on trials, "there would have been no democratic South Africa" (Tutu 1999:25).

Tutu sees other "cogent and important reasons" as well. Nüremberg style criminal trials "would have placed an unbearable burden on an already strained judicial system" (1999:27). Disturbing details from such cases aired "for an unconscionably long time would be distressing to many and disruptive of our fragile peace and stability" (1999:27). This concern apart, Tutu returns to the overriding political and security consideration: "We could very well have had retributive justice, and had a South Africa lying in ashes - a truly Pyrrhic victory if ever there was one" (1999:27).

Tutu then mentions another argument, one also raised by the then Deputy Minister of Justice, Johnny de Lange, in the first debates surrounding the TRC and the outcomes of its work. It seems to have been an important consideration for those involved, namely the uncertainties faced in our courts at the beginning of our transition in the 1990s (cf. De Lange in Villa-Vicencio and Verwoerd 2000:14-31; Boesak 2005:171-173). ${ }^{7}$ Discussing first the difficulties of presenting evidence in court to be proved "beyond reasonable doubt", Tutu then gets to the heart of the matter. First, there was the admission that much of the evidence in terms of documentation had been destroyed (1999:27; cf. Boesak 2005:191). Second, there was the question of the mendacity of those charged with human rights abuses:

7 De Lange mentions two cases that failed in court because of the reasons he and Archbishop Tutu expound upon, namely that of former Minister of Defence, Magnus Malan, and apartheid scientist, Dr Wouter Basson. 
NGTT: Oopbron - http://ngtt.journals.ac.za

We discovered in the course of the Commission's investigations that the supporters of apartheid were ready to lie at the drop of a hat. This applied to cabinet ministers and commissioners of police right down to rank-and-file supporters [They perjured themselves] brazenly and with considerable conviction (Tutu 1999:27-28).

Besides that, there was the important consideration that the majority of judges were still white,

sharing the apprehensions and prejudices of their white compatriots, secure in enjoying the privileges that the injustices of apartheid provided them with so lavishly and therefore inclined to believe that all opposition to that status quo was Communist inspired (Tutu 1999:28).

We do not find any consideration of insights like those offered by Mamdani reflected in Tutu's arguments surrounding the rejection of the Nüremberg option. While this does have consequences for where the TRC ended up, this does not mean that they were ready to "let bygones be bygones" (Tutu 1999:27-28). That would have amounted to what Tutu calls "national amnesia". "Accepting that notion would have victimised the victims of apartheid a second time around. It would have meant denying their experience, a vital part of their identity" (1999:32). However, through the TRC, "they would be empowered to tell their stories, and allowed to remember and in this public recounting their individuality and inalienable humanity would be acknowledged" (1999:32-33). Truth would be found in these stories, a truth different from the forensic, factual truth, verifiable and documentable. Not just the social truth, that is, the truth of experience that is established through interaction, discussion and debate, but the personal truth Tutu describes with the words of the late Chief Justice of the Supreme Court Ishmail Mahomed, "the truth of wounded memories" (1999:33). Tutu uses this expression several times since it is intimately related to what, for him, lay at the heart of the work of the TRC, namely ubuntu, a concept we shall return to in greater detail.

The TRC was, of course, concerned about justice. The Archbishop devotes one whole chapter titled What About Justice?, to it (Tutu 1999:47-60). The argument is a discussion on retributive justice - "in which an impersonal state hands down punishment with little consideration for the victims and hardly any for the perpetrator" (1999:51) - versus the justice the TRC preferred, namely restorative justice for reasons already mentioned above. For the TRC these were the only forms of justice they considered. Restorative justice, writes legal expert Mike Batley,

is a theory of justice that emphasises repairing the harm caused or revealed by criminal behaviour, transforming the traditional relationship between communities and their governments in responding to crime (Batley 2010:21).

Firmly embedded in criminology and victimology, restorative justice is based on three principles. First, it requires the aim of restoring those who have been injured. Second, those most directly involved and affected by crime should have the opportunity to participate fully in the process of response, and third, government's role is to preserve a just public order and the community's role to build and maintain a just peace (Batley 2010:22). Apology, changed behaviour, sincerity and restitution - the payment of a sum of money by the offender "to compensate the victim for the financial losses caused by the crime" (2010:22) - are all essential elements of successful restorative justice. However, Batley too believes that "the spirit of ubuntu" drives the process (2010:22). 
NGTT Deel 54, Nommers 3 \& 4, September en Desember 2013

It is understandable that, in its emphasis on victims, perpetrators and its request for reparations for those victims, the TRC felt the need to identify its concept of justice as restorative justice. "I contend that there is another kind of justice" (Tutu 1999:51). Such is also the view of De Lange (Villa-Vicencio and Verwoerd 2000:14-31). De Lange forcefully makes the point that the idea of a TRC did not arise from any law or from the Constitution; it is the result of "our morality as a people who want to heal our nation, and restore the faith of those in our country and the international community in our common future" (De Lange 2000:18). Archbishop Tutu claims that this understanding of restorative justice is the "traditional understanding of African jurisprudence", in which

the central concern is not retribution or punishment, but in the spirit of ubuntu, the healing of breaches, the redressing of imbalances, the restoration of broken relationships. This kind of justice seeks to rehabilitate both the victim and the perpetrator, who should be given the opportunity to be integrated into the community he or she has inured by his or her offence. This is a far more personal approach. Thus we would claim that that justice, restorative justice, is being served when efforts are being made to work for healing, for forgiveness and for reconciliation (Tutu 1999:51-52).

Tutu again and again returns to ubuntu as the foundational element in the TRC's work and links it to forgiveness and healing, justice and reconciliation, as well as amnesty and reparations: "Thus our recommendation to the President and parliament provided that a sum of money reasonably significant in amount would be paid to those designated as victims" even though it should be acknowledged that it was really meant to be symbolic rather than substantial (1999:57). Ubuntu is not just a (black) African trait; it is the gift of all South Africa's people (1999:117, 221-223) and at times even universal (1999:213).

However, the question remains: Is restorative justice adequate for what was required of the TRC? Is it really "the doing of the little righteousness" as we understand it? Restorative justice is a concept enjoined to the criminal justice system, it works with individuals and their restoration and their reintegration rather than with systemic social change. It is limited to criminal justice and personal responses to a crime and explicitly steers away from systemic socioeconomic justice, which is the main problem I have identified in the work of the TRC in this essay and elsewhere (Boesak 2005:171-212). True reconciliation means not just the healing of broken relationships (however important that may be) or even reparations - assuming the government is willing to pay for it (which this government was not and the TRC did not ask reparations from the perpetrators). Reconciliation in its deepest sense is transformation - of the individual, the community and the systems of society (economic and political) in order for justice to effect genuine restoration: of integrity, of human dignity and of human contentment, which makes reconciliation as the expression of compassionate justice and love not only possible but durable (Boesak 2008:633-654).

Our contention is not only that the TRC's only choice was not just between retributive and restorative justice, revenge and forgiveness, but following Mamdani, it was incumbent upon the TRC to advance the gains made at Kempton Park, to move from victim's justice to survivor's justice and from the foundation of political justice to social justice. For Christians, social justice is also the indispensable biblical demand and, inasmuch as the TRC vested itself with an explicitly Christian understanding of reconciliation, that demand is unavoidable and irrevocable (Tutu 1999:86; Smit 2007:325-342; Boesak 2005:171-212). 
NGTT: Oopbron - http://ngtt.journals.ac.za

I am speaking here of the justice required by the Lord that deals directly with iniquitous decrees and oppressive statues and practices. As Wolterstorff says, it is primary and rectifying justice, the overturning of injustice and the bringing of justice. This is to be done as Yahweh's and Jesus'cause, especially towards the ones at the bottom, the lowly and the downtrodden whose daily condition is one of injustice (Wolterstorff 2008:75ff.).

The TRC could have called for distributive justice, and it would have produced a better result than the mere juxtaposition of vengeful punishment and restorative justice. In this we follow Hebrew Bible scholar Walter Brueggemann who asserts:

The intention of Mosaic justice is to redistribute social goods and social power; thus it is distributive justice. This justice recognises that social goods and social power are unequally and destructively distributed in Israel's world (and derivatively in any social context), and that the wellbeing of the community requires that social goods and power to some extent be given by those who have too much, for the sake of those who do not have enough (1997:736-737).

Tutu's direct call upon Jesus at the TRC would also have made it natural for the TRC to heed the NewTestament not only in its call for forgiveness, but also in its call for radical justice, despite what Wolterstorff calls its "dejusticising" (Wolterstorff 2008:96-108) and Richard Horsley its "depoliticising" (Horsley 2003) by many. "If there is forgiveness in the New Testament", says Wolterstorff, "there has to be justice in the New Testament" (2008:109): Jesus is "the One who brings justice", is the conclusion of his utterly convincing exposition (2008:115).

\section{THE SPIRIT OF UBUNTU}

But what about ubuntu? The word has figured prominently in and since the work of the TRC. (Smit 2007:340) The latter was driven by "the spirit of ubuntu", as Archbishop Tutu states, and it was the compelling force behind the desire to find forgiveness in extraordinarily painful, almost impossible moments. Tutu speaks glowingly about ubuntu and its meaning, and he is not the only one (Lesiba Teffo in Makgoba 1999:146-169).

Not everyone sees it this way. Richard Wilson recalls how, in the amnesty process, the word ubuntu was used to persuade the victims of apartheid to once again make the sacrifices, something which "was never demanded of the perpetrators" (Graybill 2002:35; Boesak 2005:186). Convinced that ubuntu was used as a sort of emotional blackmail, Wilson rejects the term as "a current invention" (Graybill 2002:33; Boesak 2005:198).

I will not say that. Ubuntu is doubtless an enormously powerful philosophy and as a "concept of brotherhood [sic] and unity for survival" it does "empower people to love and respect each other" (Teffo 1999:164). It is indeed everything that Desmond Tutu claims, and in 1976 I already concluded my dissertation with a call upon ubuntu as "gospel truth" (Boesak 1984:152). However, the question now is whether ubuntu is an adequate concept for our situation, and for all its humanising aspects. Does it enable us to bring about the justice Christians are called to as required by the Lord?

The concept of ubuntu might doubtless have inspired some to forgive. But did it enable the doing of systemic justice and the undoing of systemic injustice? Regrettably, the answer is "no". Ubuntu led to a recommendation to the government to pay reparations and a call on the business community to play a voluntary role in compensating black people 
NGTT Deel 54, Nommers $3 \& 4$, September en Desember 2013

for the disadvantages of apartheid. But clearly, as Sampie Terreblanche correctly argues, the exploitation of blacks did not happen voluntarily. "It was compulsory and systemic", embedded in a network of compulsory legislation and justified by ideologies "that were propagated as self-evident truths". To expect big business to compensate voluntarily and to the necessary degree for injustices done over a century is both "idealistic and naïve" (Terreblanche 2000:268). Even though the ANC claims ubuntu as philosophical possession, it did not feel morally or politically compelled by it to do what was right.

Ubuntu is based on the recognition of human worth and the interconnectedness of all persons, but it has scarcely offered an imperative for the restoration of worth and human integrity of women, and certainly not for homosexual persons, for example. It assumes an interdependent humanity, but it does not speak of the systemic inequalities that today prevail in the relationships, systemic, personal and communal, of women and men, rich and poor, threatening or obliterating human dignity in South Africa. It appeals to assumptions of solidarity but it does not speak of rights and wrongs, of oppression and liberation. Justice may be implied, but it is not demanded. Nowhere is ubuntu used to critique and challenge the fact that our society is organised in a way that deliberately places some (the wealthy and privileged elite) at the top and others (the impoverished masses) at the bottom. Doing justice means that one does not only recognise that the other is human, but that the other is not trampled upon, purposely placed and kept at the bottom.

Again it is Nicholas Wolterstorff who offers an extremely valuable insight in this regard. It is an insight crucial to our understanding of justice, of rights and wrongs, and of the bringing of justice to the wronged. "Metaphors common in present day discourse", he writes, "are those of the margin and the outside" (Wolterstorff 2008:123-124). Some people are in the centre, some on the circumference, and some are on the outside. However, Biblical writers worked instead with the image of up and down. Some are at the top of the social hierarchy and some are at the bottom. They are at the bottom not because of their own fault; they are there because they are downtrodden. Those at the top "trample the heads of the poor into the dust of the earth" (Amos 2:7).

When centre and circumference are one's basic metaphors, the undoing of justice will be described as including the outsiders. When up and down are one's basic metaphors, the undoing of injustice will be described as lifting up those at the bottom. The poor do not have to be included in the social order; they have always been there, usually indispensable to its functioning. They have to be lifted up (2008:123).

The aim, it seems to me, is not charity or even solidarity, but equality:

God raises the poor from the dust,

And lifts the needy from the ash heap

To make them sit with princes (Ps. 113:7).

This is also true of the New Testament, Wolterstorff argues. A striking feature of the New Testament writings and of Jesus' preaching is the frequency with which the up-and-down metaphor, so common in the writings of the Old Testament, is employed to say something that the Old Testament writers at most hint at. "The rectification of injustice requires not only the lifting up of the low ones but casting down the high ones. The coming of justice requires social inversion" (Wolterstorff 2008:123). 
NGTT: Oopbron - http://ngtt.journals.ac.za

Ubuntu knows no such call. It is a wonderful concept that calls upon values without which human community is not really possible, but justice is irreplaceable. Ubuntu needs the imperative to the doing of justice and the undoing of injustice that is so pervasive in the Bible, the imperative towards the radical overturning of the unjust social order so that justice is done. For the doing of even the little righteousness we need the full power of the conviction that justice is Yahweh's cause, as it is the cause of Jesus; that the pursuit of justice for the lowly and the downtrodden, the weak and the wronged is our enduring calling: "Justice and only justice you shall pursue" (Deut. 16:18-20).

Beyond Kempton Park and the TRC this remains our responsibility. Not on our own, as Dirkie Smit reminds us, but "alongside suffering and hopeless people", not "with good words alone" or as "weary sceptics", but doing what we must do "even at the risk of making mistakes", helping those who suffer "by strengthening their courage not to be content with the corruption and evil of the world but even within this horizon to look ahead and not back" (Smit 2007:371).

\section{BIBLIOGRAPHY}

Batley, M. 2010. Restorative Justice in the South African Context. Online at: www.iss.co.za/pubs/ monographs/No 111/Chapter 2. [2011, February 11].

Boesak, A. A. (1977) 1984. Farewell to Innocence. A SocioEthical Study of Black Theology and Black Power. Maryknoll, NY: Orbis.

Boesak, A. A. 2005. The Tenderness of Conscience. African Renaissance and the Spirituality of Politics. Stellenbosch: Sun Press.

Boesak, A. A. 2008. And Zacchaeus Remained in the Tree: Reconciliation and Justice and the Truth and Reconciliation Commission. Verbum et Ecclesia 29(3), 636654.

Boesak, A. A. 2009. Running with Horses. Reflections of an Accidental Politician. Cape Town: JoHo!

Centre for Justice and Reconciliation, Washington DC, Restorative Justice Briefing Paper. Online at: http:// www.pfc.org/cjr/restorativejustice/introduction. [2011, February 11]. Cone, J. H. (1975) 1997. God of the Oppressed. Maryknoll, NY: Orbis.

De Lange, J. 2000. The Historical Context, Legal Origins and Philosophical Foundation of the South African Truth and Reconciliation Commission. In VillaVicencio C. and Verwoerd, W. (eds.), Looking Back, Reaching Forward. Cape Town: UCT Press/London: Zed, 14-31.

Graybill, L. S. 2002. Truth and Reconciliation in South Africa. Boulder, CO/London: Lynne Rienier.

Mamdani, M. 1996. Reconciliation without Justice. Southern African Review of Books, Issue 46, November/ December, 35.

Mamdani, M. 2010. Beyond Kempton Park: Reflections on Nuremberg and the Question of Justice. Paper delivered at the Africa Memorial Day Conference, University of the Free State, Bloemfontein, July 14, 2010.

Smit, D. J. 2007. Essays in Public Theology. Collected Essays 1. Conradie, E. M. (ed.).Stellenbosch: Sun Press.

Smit, D. J. 2007. "The Doing of the Little Righteousness" - On Justice in Barth's View of the Christian Life. In Essays in Public Theology. Collected Essays 1, 359-378.

Smit, D. J. 2009. Essays on Being Reformed. Collected Essays 3. Vosloo, R. R (ed.).Stellenbosch: Sun Press.

Teffo, L. 1999. Moral Renewal and African Experience(s). In Makgoba, M. W. (ed.), African Renaissance. Cape Town: Tafelberg and Mafube, 149-169.

Terreblanche, S. J. 2000. Dealing with Systemic Economic Injustice. In VillaVicencio, C. and Verwoerd, W. (eds.), Looking Back Reaching Forward. Cape Town: UCT Press/London: Zed, 265-278.

Tutu, D. M. 1999. No Future without Forgiveness. Johannesburg/Auckland/ London/Sydney: Random House.

Wolterstorff, N. 2008. Justice, Rights and Wrongs. Princeton, NJ and Oxford: Princeton University Press. 
NGTT Deel 54, Nommers 3 \& 4, September en Desember 2013

\section{KEY WORDS}

Dirkie Smit

Forms of Justice

Truth and Reconciliation Commission

Mahmood Mamdami

Ubuntu

\section{TREFWOORDE}

Dirkie Smit

Vorme van Geregtigheid

Waarheids-en-Versoeningskomissie

Mahmood Mamdami

Ubuntu

Contact Details/Kontakbesonderhede

Prof Allan Boesak

Postnet Suite 285

Private Bag X15

Somerset West

7130

E-pos: boesak@mweb.co.za 